\section{Effects of early experience with electric shock and dexamethasone on avoidance conditioning at adulthood*}

\author{
LEE J. GROTA and ROBERT ADER \\ University of Rochester School of Medicine and Dentistry \\ Rochester, N.Y. 14642
}

The effects of dexamethasone on adult avoidance behavior and plasma corticosterone levels was observed in rats subjected to electric shock stimulation and/or dexamethasone treatment during early life. In the absence of dexamethasone, early stimulation increased the number of avoidance responses. Dexamethasone did not influence avoidance behavior in any systematic manner, but did decrease corticosterone levels when administered at maturity. Electric shock stimulation during infancy resulted in lower corticosterone levels relative to unmanipulated controls whether or not these animals had been treated with dexamethasone.

Stimulation of the rat with electric shock during early infancy and during the immediate postweaning period has been shown to influence subsequent avoidance behavior (Ader \& Schaefer, 1968; Denenberg \& Karas, 1960; Denenberg \& Smith, 1963; Levine, 1956 ) and to reduce adrenocortical reactivity (Ader \& Grota, 1969; Hess, Denenberg, Zarrow, \& Pfeifer, 1969; Levine, Haltmeyer, Karas, \& Denenberg, 1967). Moreover, it has been hypothesized (Levine \& Mullins, 1966; Zarrow, Philpott, Denenberg, \& O'Conner, 1968) that the reduced adrenocortical reactivity and the behavioral effects of stimulating rats during infancy are the common result of an increase in circulating steroids which are released in response to the stimulation experienced during development. Recent data obtained by Grota (1972), however, failed to support this hypothesis. During the first 17 days of life, animals were provided with drinking water containing dexamethasone, a synthetic glucocorticoid which blocks the release of ACTH in response to environmental stimulation (Fraschini, Motta, \& Martini, 1966). The doses used were sufficient to block the elevation in plasma corticosterone in the lactating female alone or in both the lactating female and the young in response to removing the pups from the nest and subjecting them to electric shock stimulation. Under these conditions, a reduction in adrenocortical reactivity to electric shock was still observed in the previously stimulated animals, as reflected in plasma levels of corticosterone sampled between 17

*This research was supported by USPHS
Grants $\mathrm{HH}-16.741$ and $\mathrm{K} 5-\mathrm{MH}-6318$ from Grants $\mathrm{MH}-16.741$ and $\mathrm{K5}-\mathrm{MH}-6318$ fro
the National Institute of Mental Health. and 21 days of age. The purpose of the present study was to extend these observations to adult behavior and adrenocortical reactivity.

Recent studies of pituitary-adrenal influences on behavior have emphasized the effects of adrenocorticotrophic hormones on the acquisition and extinction of conditioned avoidance responses (e.g., de Wied, 1969). The acquisition of a conditioned avoidance response, however, is not affected by treatment with dexamethasone (Beatty, Beatty, Bowman, \& Gilchrist, 1970; Kasper-Pandi, Hansing, \& Usher, 1970). A secondary aim of the present study, then, was to determine if dexamethasone would influence the acquisition of a response based on the avoidance of electric shock in animals that had previously experienced electric shock and treatment with dexamethasone during early life.

$$
\text { METHOD }
$$

Charles River (CD) rats were obtained commercially, and housed and bred in our laboratory, as needed. Eight to 10 male pups born within a 24-h period were pooled to make up the litters for this experiment. As in a previous study (Grota, 1972), litters were provided with plain water or water containing 63 or

Table 1

Effects of Dexamethasone Treatment on Number of Avoidance Responses (Mean \pm SE) as a Function of Electric Shock Stimulation and Dexamethasone Treatment During Infancy

\begin{tabular}{|c|c|c|c|c|c|}
\hline & & \multicolumn{4}{|c|}{ Adult Treatment } \\
\hline \multicolumn{2}{|c|}{$\begin{array}{c}\text { Treatment } \\
\text { During Infancy }\end{array}$} & Water & $\mathbf{N}$ & $\begin{array}{l}\text { Dexameth- } \\
\text { asone }\end{array}$ & $\mathbf{N}$ \\
\hline Shock & $\begin{array}{l}\text { Water } \\
63 \mu \mathrm{g} \\
250 \mu \mathrm{g}\end{array}$ & $\begin{array}{l}67.4 \pm 2.9 \\
55.8 \pm 4.6 \\
60.0 \pm 4.2\end{array}$ & $\begin{array}{r}11 \\
9 \\
11\end{array}$ & $\begin{array}{l}42.4 \pm 4.7 \\
57.6 \pm 5.7 \\
70.5 \pm 2.3\end{array}$ & $\begin{array}{r}10 \\
9 \\
11\end{array}$ \\
\hline No Shock & $\begin{array}{l}\text { Water } \\
63 \mu \mathrm{g} \\
250 \mu \mathrm{g}\end{array}$ & $\begin{array}{l}48.4 \pm 5.3 \\
58.1 \pm 5.0 \\
64.6 \pm 3.8\end{array}$ & $\begin{array}{r}10 \\
9 \\
7\end{array}$ & $\begin{array}{l}58.2 \pm 2.9 \\
63.6 \pm 4.7 \\
48.7 \pm 5.8\end{array}$ & $\begin{array}{r}9 \\
9 \\
10\end{array}$ \\
\hline
\end{tabular}

250 micrograms of dexamethasone in the 8-oz drinking bottle of the mother on Days 2.17 after birth. Half of the litters from each of these groups were subjected to a daily $3-\mathrm{min}$ period of scrambled electric shock on Days 3-17; the remaining animals were unmanipulated. All animals were maintained on plain water after Day 17, weaned on Day 21, and housed individually thereafter.

At 100 days of age, each group of animals was subdivided randomly into control (water) and dexamethasonetreated (250 micrograms/8-oz drinking bottle) conditions. After 1 week of this treatment, half of the animals were given 100 trials in an automated avoidance conditioning apparatus containing retractable platforms (levers). A cue light served as the CS, and scrambled electric shock (approximately $0.8 \mathrm{~mA}$ ) served as the US. Any depression of the platform within the 8-sec CS-US interval served to terminate the CS and avoid shock. The intertrial interval varied between 40 and $100 \mathrm{sec}$. The nonconditioned animals were placed into duplicate chambers that did not contain response levers. This "yoked" group received the same number and distribution of electric shocks as the conditioned Ss but were unable to perform any leverpressing response.

Immediately after the 100 conditioning trials, the animals were lightly anesthetized with ether and blood samples were drawn by cardiac puncture. Plasma corticosterone concentration was determined by methods described elsewhere (Friedman, Ader, Grota, \& Larson, 1967). The laboratory was maintained under a 12-h light-dark cycle, avoidance conditioning began $1 \mathrm{~h}$ before, and the blood samples were collected at the peak in the rats' 24 -h adrenocortical rhythm (Ader, 1969). RESULTS AND DISCUSSION

The number of avoidance responses made by all groups on the 100 conditioning trials is given in Table 1. An initial comparison was made between the previously shocked and unmanipulated animals that were maintained on plain water throughout 
Table 2

Effects of Dexamethasone Treatment on Mean ( \pm SE) Plasma Corticosterone Levels ( $\mu \mathrm{g} / 100$ ml) Following Avoidance Conditioning as a Function of Electric Shock Stimulation and Dexamethasone Treatment During Infancy

\begin{tabular}{|c|c|c|c|c|c|c|c|c|c|}
\hline \multirow{3}{*}{\multicolumn{2}{|c|}{$\begin{array}{c}\text { Treatment } \\
\text { During Infancy }\end{array}$}} & \multicolumn{8}{|c|}{ Aduit Treatment } \\
\hline & & \multicolumn{4}{|c|}{ Water } & \multicolumn{4}{|c|}{ Dexamethasone } \\
\hline & & Conditioned & $\mathbf{N}$ & Yoked & $\mathbf{N}$ & Conditioned & $\mathbf{N}$ & Yoked & $\mathbf{N}$ \\
\hline Shock & $\begin{array}{l}\text { Water } \\
63 \mu \mathrm{g} \\
250 \mu \mathrm{g}\end{array}$ & $\begin{array}{l}29.9 \pm 2.5 \\
24.4 \pm 2.9 \\
28.1 \pm 1.8\end{array}$ & $\begin{array}{r}11 \\
9 \\
11\end{array}$ & $\begin{array}{l}26.4 \pm 3.1 \\
22.9 \pm 2.0 \\
23.6 \pm 2.2\end{array}$ & $\begin{array}{r}11 \\
9 \\
11\end{array}$ & $\begin{array}{l}8.4 \pm 2.5 \\
8.3 \pm 3.0 \\
9.3 \pm 2.0\end{array}$ & $\begin{array}{r}10 \\
9 \\
11\end{array}$ & $\begin{array}{l}7.6 \pm 1.5 \\
7.7 \pm 1.4 \\
8.3 \pm 2.5\end{array}$ & $\begin{array}{r}10 \\
9 \\
11\end{array}$ \\
\hline No Shock & $\begin{array}{l}\text { Water } \\
63 \mu \mathrm{g} \\
250 \mu \mathrm{g}\end{array}$ & $\begin{array}{l}31.6 \pm 3.4 \\
33.6 \pm 2.7 \\
30.0 \pm 5.6\end{array}$ & $\begin{array}{r}10 \\
9 \\
7\end{array}$ & $\begin{array}{l}31.8 \pm 3.0 \\
27.6 \pm 3.0 \\
34.7 \pm 3.2\end{array}$ & $\begin{array}{r}10 \\
9 \\
7\end{array}$ & $\begin{array}{l}12.0 \pm 2.0 \\
15.2 \pm 3.1 \\
13.9 \pm 2.8\end{array}$ & $\begin{array}{r}9 \\
9 \\
10\end{array}$ & $\begin{array}{r}9.3 \pm 2.3 \\
13.8 \pm 3.8 \\
9.5 \pm 2.2\end{array}$ & $\begin{array}{r}9 \\
9 \\
10\end{array}$ \\
\hline
\end{tabular}

the experiment in order to determine if the present results would substantiate the reports that electric shock experienced during early life influences subsequent avoidance behavior. Animals shocked during infancy made significantly more avoidance responses than did the unmanipulated controls $(\mathrm{t}=3.22$, $\mathrm{p}<.01)$. This difference, in the absence of dexamethasone treatment, is consistent with the earlier findings cited above. An overall analysis of variance applied to the number of avoidance responses yielded only an interaction between early stimulation, early drug experience, and adult drug treatment $(\mathrm{F}=3.15$, df $=2 / 103$, $\mathrm{p}<.05$ ), but no consistent pattern could be discerned in these data. Among the animals subjected to avoidance conditioning while being maintained on plain water, early treatment with dexamethasone did influence avoidance behavior. Dexamethasone decreased effective avoidance performance of the animals that were shocked during early life relative to the shocked animals that received plain water during infancy. In contrast, however, early treatment with dexamethasone increased the number of avoidance responses that were made by animals that were not shocked in infancy. This interaction obviates any definitive conclusion with respect to the adrenocortical mediation of such early experience effects.

Dexamethasone perse did not influence avoidance behavior, which is, again, consistent with previous findings (Beatty et al, 1970 ; Kasper-Pandi et al, 1970). Nor was there any evidence that prior treatment with dexamethasone would interact with subsequent treatment in any systematic way to influence aversively motivated behavior.

Dexamethasone treatment was effective in reducing adrenocortical activity. These data are shown in Table 2. Immediately after avoidance conditioning, the mean concentration of corticosterone was 10.2 \pm 0.7 micrograms percent for the animals treated with dexamethasone compared to a mean of 28.6 \pm 0.8 micrograms percent for the animals maintained on plain water ( $F$ $=271, \mathrm{df}=1 / 206, \mathrm{p}<.01)$. The analysis of variance revealed no interactions, and there were no differences between animals treated with dexamethasone or water during infancy or between conditioned and "yoked" animals. There was, however, a significant main effect of early stimulation; the mean corticosterone level of $17.0 \pm 0.6$ micrograms percent for the animals subjected to electric shock stimulation during infancy was significantly lower than the mean of $21.8 \pm 0.8 \mathrm{micrograms}$ percent obtained from the nonshocked groups $(F=18.4, \mathrm{df}=1 / 206, \mathrm{p}<.01)$.

Although prestimulation levels of corticosterone are not generally different as a function of early experimental manipulation (Ader \& Grota, 1969; Grota, 1972; Hess et al, 1969; Levine et al, 1967), it may not be strictly appropriate to refer to these data as reflecting adrenocortical reactivity, since corticosterone samples were not obtained before the period of avoidance conditioning. Nonetheless, the poststimulation values that were obtained do confirm previous observation that early stimulation effects a reduction in adrenal function, and they suggest further that this characteristic difference between previously stimulated and unstimulated animals obtains even when there was little or no adrenocortical response to the stimulation experienced during early life.

Our data on conditioned avoidance behavior confirmed the superiority of animals that experienced electric shock stimulation during infancy relative to unmanipulated controls. These data, though, were equivocal with respect to the effects of early treatment with dexamethasone, an ACTH inhibitor, and therefore with respect to the adrenocortical system as the mediator of these behavioral effects. The differences in plasma corticosterone levels observed in the present study confirmed and extended the recent results obtained by Grota
(1972). Using doses of dexamethasone sufficient to block the elevation of corticosterone levels of the mother or of the mother and the litter in response to stimulation of the pups, Grota found that such stimulation still reduced adrenocortical reactivity at weaning. In the present study, early treatment with dexamethasone had no influence on the difference in plasma corticosterone levels of adult animals that had experienced electric shock or had remained unmanipulated during the preweaning period. These data, then, provide no support for the hypothesis that an adrenocortical response by either the mother or the young is responsible for the effects of stimulation during infancy on subsequent adrenocortical function.

\section{REFERENCES}

ADER, R. Early experiences accelerate maturation of the 24-hour adrenocortical rhythm. Science, 1969, 163, 1225-1226.

ADER, R., \& GROTA, L. J. Effects of early experience on adrenocortical reactivity. Physiology \& Behavior, 1969, 4, 303-305.

ADER, R., \& SCHAEFER, A. Effects of early experiences on one-trial avoidance conditioning. Psychonomic Science, $1968,10,235-236$.

BEATTY, P. A., BEATTY, W. W., BOWMAN, R. E., \& GILCHRIST, J. C. The effects of ACTH, adrenalectomy, and dexamethasone on acquisition of an avoidance response in rats. Physiology \& Behavior, 1970, 5, 939-944.

DENENBERG, V. H., \& KARAS, G. G. Interactive effects of age and duration of infantile experience on adult learning. Psychological Reports, 1960, 7, 313-322.

DENENBERG, V. H., \& SMITH, S. A. Effects of infantile stimulation and age upon behavior. Journal of Comparative \& Physiological Psychology, 1963, 56, 307-312.

de WIED, D. Effects of peptide hormones on behavior. In W, F, Ganong and $L$. Martini (Eds.), Frontiers in neuroendocrinology. New York: Oxford, 1969.

FRASCHINI, F., MOTTA, M., \& MARTINI, L. Methods for evaluation of hypothalamic hypophysiotropic principles. In $P$. Mantegazza and $F$. Piccinini (Eds.), Methods in drug evaluation. Amsterdam: North Holland. 1966.

FRIEDMAN, S. B., ADER, R., GROTA, L. J., \& LARSON, T. Plasma corticosterone response to parameters of electric shock stimulation in the rat. Psychosomatic Medicine, 1967, 29, 323-328.

GROTA, L. J. Effects of early experience and dexamethasone on adrenocortical reactivity. Paper presented at Eastern Psychological Association meeting, April 
1972

HESS. J. L.. DENENBERG. V. H.. ZARROW, M. X., \& PFEIFFER. W. D. Modification of the corticosterone response curve as a function of handling in infancy. Physiology \& Behavior. 1969. 4. 109-111.

KASPER-PANDI, P.. HANSING. R.. \& USHER, D. R. The effect of dexamethasone blockade of ACTH release on avoidance learning. Physiology \& Behavior. 1970,5,361-363.

LEVINE. S. A further study of infantile banding and adult avoidance conditioning. Journal of Personality. 1956. 25 . 70-80.

LEVINE, S.. HALTMEYER, G.C. KARAS G. G. \& DENENBERG V H Physiological and behavioral effects of infantile stimulation. Physiology \&
Behavior. 1967, 2, 55-59.

LEVINE, S. \& MULLINS, R. F. Hormona influences on brain organization in infant rats. Science, $1966,152,1585-1592$.

ZARROW. M. X., PHILPOTT, J. E. DENENBERG, V. H. \& O'CONNER, W. B. Localization of $\mathrm{C}$-4-corticosterone in the 2-day-old rat and a consideration of the mechanisms involved in early handling. Nature, $1968,218,1264-1265$. 